\title{
Predicting E-Government Use in Mauritius: Non-Parametric Procedures
}

\author{
Chintamanee Sanmukhiya
}

\begin{abstract}
This study changes the way in which research has so far been conducted on assessing the extent to which the UTAUT model predicts the use of e-government. It also contributes to the theoretical framework by adding up a trust component to forecast behavioural intention. This study adds other factors to the theoretical model such as frequency of use, sector of occupation, education and urbanisation. Instead of merely summing up Likert-type items, this research identifies those individual factors behind all UTAUT components and Trust dimension that predict the use of the Mauritian government website both in the short and long run under the non-parametric approach. Mann-Whitney U tests, Kruskal-Wallis H tests, Bonferroni correction and Jonckheere-Terpstra testsare used throughout the analysis. Data were randomly collected through questionnaires across 221 citizens who use the government website in Mauritius.
\end{abstract}

Factors such as adequate knowledge, self_confidence, convenience of use, support at work, influential people, opinions of valued people, recommendations by important people to use the e-portal, improved job performance, ability to complete task online, having useful and required information online, ease of finding information, trust in government departments and website, online security and non-disclosure of personal details to third party affect a citizen's intention to continue to use e-government portal in the future. In addition to these factors, having a computer or laptop, and cheap internet subscription affect short term behavioural intention but not long term behavioural intention. The reverse applies for updated information, easy to understand and use, maintain confidentiality, the enactment of laws against cybercrimes and seen as competent by colleagues. Results are significant at $0.1 \%, 1 \%$ and $5 \%$ level. Frequency of use and sector of occupation play key roles in influencing a citizen's desire to use government websites across all UTAUT and Trust components. Urbanisation however does not affect e-government use at all. This study enables policymakers and government website administrators to tackle those aspects that may favourably mould citizens' perceptions towards the government website. It will thus enhance e-government practice in Mauritius.

Index Terms: E-Government, UTAUT Model, Bonferroni Correction, Kruskal-Wallis H Tests, Mann-Whitney H Tests, Jonckheere-Terpstra Tests.

\section{INTRODUCTION}

E-government is viewed as an innovation in public administration and public service delivery. Traditionally

Revised Manuscript Received on September 22, 2019

Chintamanee Sanmukhiya, Greenwich University Department Of Economics And Finance government departments have been viewed as being inefficient with long procedures and waiting queues as government officials lack motivation and there is no alternative provider of public services [1]. E-government is the provision of government services through a single access point which spans over 24 hours a day and 7 days a week [2] whereby each citizen receives identical information and public services from the government [3] at the mere touch of a button [4].

This paper examines the use of government websites by citizens over the short and long term. This study proposes an innovative methodology to assess the factors that explains e-government use within the Unified Theory of Acceptance and Use of Technology (UTAUT) model and also proposes the inclusion of the component 'Trust'. Non-parametric procedures were deemed most appropriate as these would enable the policymakers to gain an insight into the likert-type items that predict the use of the government website. The world is complex and so are its inhabitants, findings based on latent factors would not fully capture real-life situations. Through the use of nonparametric procedures, this study will assist the Mauritian government to identify those factors that are fundamental for the continued use of e-government services.

As pointed out by Al-Shafi and Weerakkody [5] the gap between implementation and e-government adoption has been widening and there is poor return on digital investment. Thus, there is a need to investigate into this situation. The objectives of this research are as follows:

- To understand the relationship between public service delivery and e-government usage in Mauritius

- To determine items which predict the continued use of government website in Mauritius over the short and long term within the UTAUT core components and Trust dimension.

- To determine the demographic and website-related factors which affect the core components of the UTAUT model and Trust dimension that eventually affect the continued use of the Mauritian government website.

- To examine the overall practical implications of findings in an attempt to improve e-government practice in Mauritius.

This study will bridge the gap between citizens and government website administrators. It is based on citizens' perceptions of e-government services offered

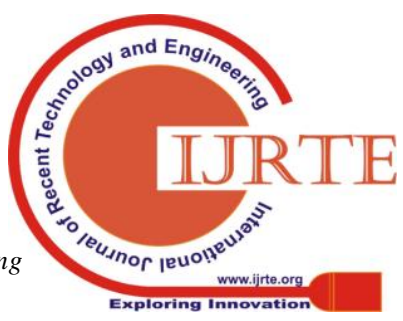


by the Mauritian government. Here e-government use is measured through the use of the government website.

\section{LITERATURE REVIEW}

The Unified Theory of Acceptance and Use of Technology (UTAUT) model was developed by Venkatesh, Morris [6] to address the shortcomings of the Technology Acceptance Model developed earlier by Davis [7]. Several studies have used the UTAUT model as it incorporates various important aspects of previous models which study the acceptance and use of technology in various fields such as e-books [8], social media [9], rural tourism [10], mobile wallet [11], tablet devices [12] mobile banking [13], mobile shopping behaviours [14] and MLearning in higher education [15]. Qualitative approach has also been used to investigate the UTAUT model [16, 17]. Given its popularity among researchers, it is deemed to be the most appropriate framework for examining the factors that may affect the continued use of the government website 'http://www.govmu.org' in Mauritius in the short term and long term. This study also adds a dimension entitled 'Trust' to the UTAUT model. Various studies have pinpointed its importance in predicting the adoption of technology. Winning citizens' trust is the primary hurdle that must be overcome to ensure the use of government websites [18-20].

The Unified Theory of Acceptance and Use of Technology (UTAUT) as developed by Venkatesh, Morris [6] is used as the theoretical framework for this study. The UTAUT model incorporates key aspects of eight competing models: the Diffusion of Innovation [21], Theory of Planned Behaviour [22], Motivational Model of Computer Usage [23], Technology Acceptance Model [7], Extension of TAM, that is TAM2 [24], Theory of Reasoned Action [25], the combined TAM and TPB (C-TAM-TPB) [26], Model of PC Utilization [27] and Social Cognitive theory [28]. Given that acceptance and use of technology is a complex phenomenon, each of these theories may be inadequate on their own to predict technology acceptance and use, for instance, Yi, Jackson [29] proposed the integration of 3 models to predict acceptance of technology among healthcare professionals in the U.S. The UTAUT model was initially developed to account for the deficiencies associated with previous models and it gained popularity as it explained around $70 \%$ of total variations in technology adoption unlike other models that explained around $40 \%$ of the technology adoption behaviour [30]. Despite modifications to include aspects such as perceived playfulness, system interactivity, cyberloafing and attention focus, many studies have supported the UTAUT model as a being an appropriate theoretical framework to explain the adoption of new technology [31-38]

The UTAUT model has four core components namely performance expectancy, effort expectancy, social influence and facilitating conditions [6]. Performance expectancy is the extent to which adoption of technology will improve job performance. Effort expectancy is the degree of ease associated with the use of the technology. Social influence is the extent to which an individual believes that others will want him/her to use the technology. Facilitating conditions refers to the existing technical infrastructures required for the use of the technology. Performance expectancy, effort expectancy and social influence were argued to be direct predictors of behavioural intention whereas facilitation conditions and behavioural intention were argued to be direct predictors of usage behaviour. These predictors explained e-government adoption for the State of Qatar [5]. Facilitating condition is an important determinant of usage. Access to internet in terms of infrastructure, IT skills and affordability is an important pre-requisite. Out of 176 countries in 2016, Mauritius was ranked $72^{\text {nd }}$ with an ICT development index of 5.88 which exceeded the global average. At the same time it was ranked $1^{\text {st }}$ in the African region. Whilst $63.3 \%$ of the Mauritian households had access to the Internet in 2016 [39], only 53.2\% of the population was using the Internet [40].

Gender, age, experience with the system and voluntariness of use were introduced into the UTAUT model as moderators [6]. Gender and age moderated the positive relationship between performance expectancy and behavioural intention whereby the effect would be bigger for younger men. Gender, age and experience moderated the positive relationship between effort expectancy and behavioural intention whereby the impact would be stronger for younger women with less experience. Age, gender, experience and voluntariness moderate the relationship between social influence and behavioural intention whereby the effect is stronger among older women with less experience. Facilitating condition has a positive and direct relationship with actual usage and becomes insignificant in predicting behavioural intention in the presence of performance expectancy and effort expectancy. The moderating effect is stronger among older people who are more experienced. Other moderating factors such as income, education, language diversity, culture differences, personality traits, rural population, country, frequency of use and occupation have also been proven to play important roles in explaining technology adoption [41-44]. Also user experience affects behavioural intention. Slow response and inconvenient input may add to negative user experience [45]. If the citizens have to wait for the government webpage to load during a long time, they may decide not to continue to use the government website.

Trust may be interpreted in terms of confidence and belief in the technology [46] or the willingness of the individual to accept vulnerability with expectations that the other party will behave positively in a situation of interdependence and risks [47]. In the case of e-government, trust is about trust in government and trust in technology [48]. Trust has been found to be the most important determinant of behavioural intention especially in the context of online payments [49, 50]. Trust is about the merchant's perceived integrity, that is, the extent to which customers believe him/ her to be honest and sincere. The level of trust may be influenced through effective interfaces such as links to emails and

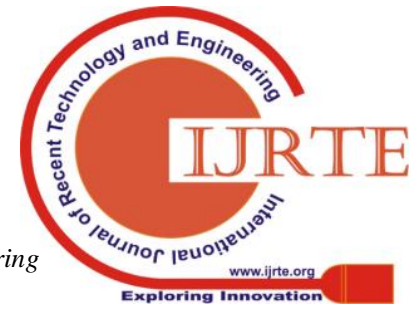


help buttons; commitment to continuous online service; and privacy and security statements [51]. Trust may also be interpreted as perceived technology security which reflects the uncertainty involved in the use of technology and the inability or the unwillingness of the seller to safeguard the buyer's monetary information [52]. Elsheikh and Azzeh [53] describe perceived trust as trust in government and trust in e-government services which positively affect behavioural intention and usage. E-government involves the exchange of personal details such as the insertion of credit card details which may entail a breach of privacy or misuse of information [32]. Also Foon and Fah [54] proposed a combination of the UTAUT core components and trust for explaining internet banking adoption where performance expectancy, effort expectancy, social influence, facilitating condition and trust were significantly and positively correlated with behavioural intention. The quality of information available on the government website or the content of the website may affect also perceived trust [55]. Confidentiality and trust affect the end user's intention to use the government website despite the rapid adoption of ICT. Security threats cause the citizens to question the integrity of the government and the e-services it provides. The solution lies in creating public trust and participation [56].

\section{METHODOLOGY}

In this study, performance expectancy refers exclusively to the extent to which the use of the government website would allow citizens and public officers to access the required information, application of online services, submission of documents and completion of tasks to benefit from e-government services. Effort expectancy is similar to TAM's perceived ease of use. Here it refers to the extent to which citizens and government officers find it easy to use the government website. Social influence here refers to the social and professional pressures that individuals undergo. They tend to be influenced by their colleagues, family and friends. Here social influence is about the extent to which these inspire citizens and government officers to use the government website. Facilitating condition in this study refers to the existing infrastructures in terms of technical skills, users' confidence, organisational support and physical infrastructures that would encourage the use of the government website.

Frequency of use was incorporated into the modified UTAUT model to control for the psychological phenomenon called 'mere exposure effect' whereby higher exposure translates into higher appreciation [57]. E-government users were categorised into 5 groups, ranging from very rare to daily users. Also the UTAUT model postulates a direct relationship between facilitating conditions and actual usage, and no relationship between facilitating condition and behavioural intention. However a strong and positive correlation exists between actual usage and behavioural intention [33]. Thus in this study, it is hypothesized that facilitating condition is directly related to behavioural intention. All behavioural intention however do not translate into usage [26].

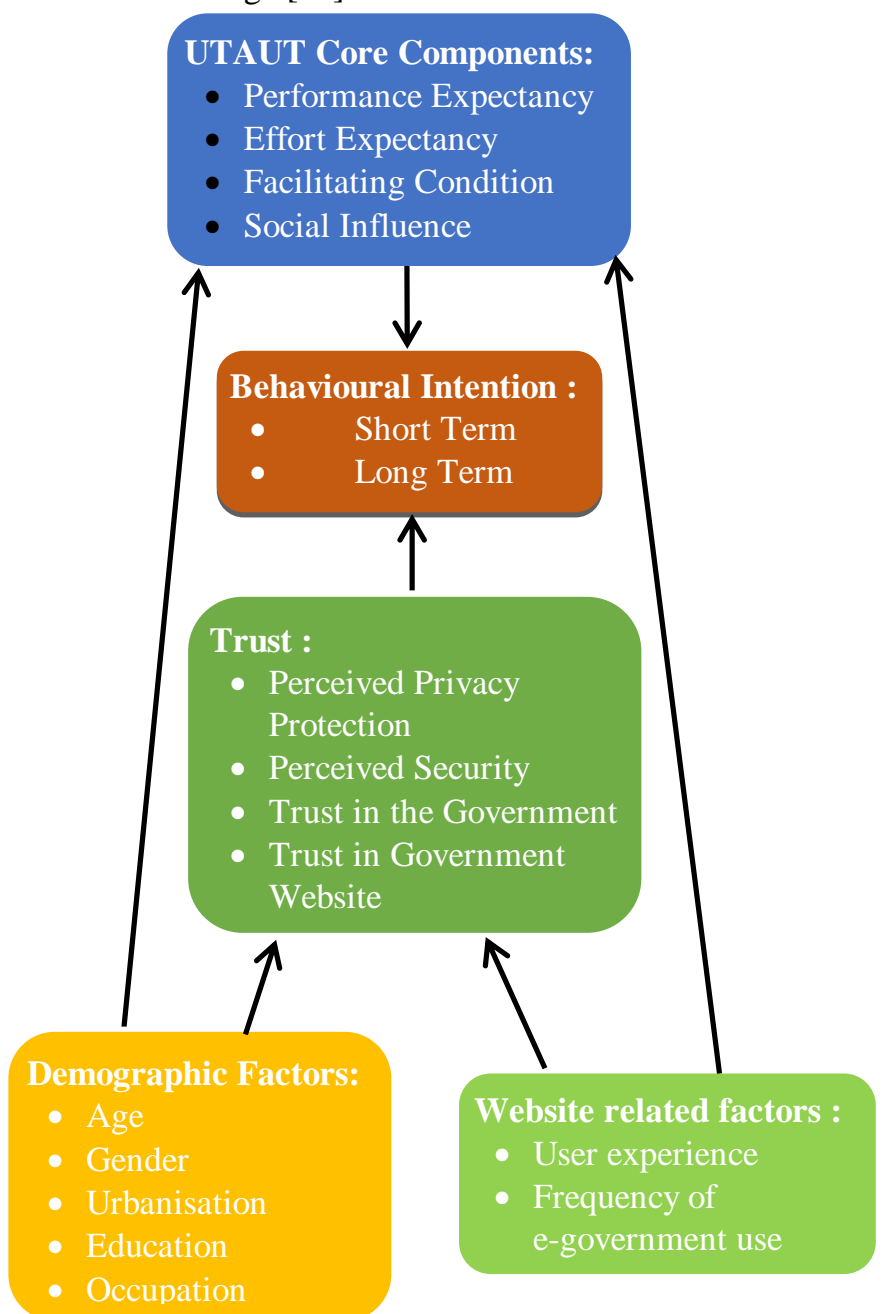

Fig. 1: Proposed Research Model

\section{A. Data Collection}

In order to understand the reasons behind the continued use of the Mauritian government website, a random survey was carried out among 240 citizens who claimed to use the government website. However 221 questionnaires only were used during the analysis stage because these contained the required information. This survey was carried out at different strategic locations in Mauritius so as to get a nationally representative sample of e-government users. Volunteers were asked to fill in the questionnaires. They remained anonymous and no attempt was made to trace them once the survey was completed. A pilot study was first conducted among 20 individuals to check for any ambiguity and other aspects that might have been unintentionally ignored by the researcher. The final questionnaire was modified accordingly and the respondents took on average 10 minutes to complete it.

\section{B. Questionnaire Design}

A five point scale for 29 Likert type items ranging from strongly disagree to strongly agree was used to indicate the extent to which each citizen agreed/disagreed with each item. The items on the questionnaire focussed on five dimensions namely 
performance expectancy, effort expectancy, social influence, facilitating conditions and trust. These are hypothesized to impact on behavioural intention in the short run and long run. Behavioural intention in the short run is captured through the item 'I intend to use the government website over the next 3 months' whereas behavioural intention in the long run is measured by 'I predict that I would continue to use the government website in the future'. Most studies have computed Cronbach alphas and constructed both valid and reliable scale. However in the process they created an aggregated scale where the individual item in the scale loses its identity and its impacts could not be distinguished from the impacts of other items in the scale.

Unlike these studies, this paper adopts non-parametric procedures to examine the factors that influence the continued use of the e-government portal in Mauritius. Each item is first analysed on its own under its dimension and any link (if ever) to behavioural intention is reported and implications are discussed at length. Eventually the aggregated impacts are considered. All items on the questionnaire have been validated through intensive literature and empirical reviews.

\section{Statistical Tests}

E-government here refers to the use of the Mauritian government website. For the purpose of this research, the Mann Whitney U test was conducted for the demographic factors: gender and urbanisation. Kruskal Wallis $\mathrm{H}$ test was done for the nominal demographic factor with more than 2 categories, that is, sector of occupation and for studying the impact between each item on the questionnaire and behavioural intention. Jonckheere-Terpstra test was conducted for those demographic and website-related factors that have ordered patterns, that is, age, education level, frequency of e-government use and user experience.

In the case of the nominal variable, sector of occupation which had more than 2 categories, it was necessary to determine which categories were statistically significantly different from each other and thus two Mann-Whitney U tests were done as follow up under each component (PE, EE, FC, SI and trust), based on a selective set of comparisons. The control group was public sector. Then the Bonferroni correction was done to ensure that Type I error remains below 0.05 and the critical significance level was 0.025 (that is, 0.05 divided by the number of tests conducted) instead of the conventional 0.05 .

Initially citizens' intention to continue to use the Mauritian government website in the short run and long run were predicted; and eventually the impacts of age, frequency of e-government use and gender on the significant predictors of e-government use were computed. Effect size which shows the size of the difference between two groups [58-60] is also reported throughout this paper. The effects with $r$ values of $0.10,0.30$ and 0.50 respectively are considered to be small, medium and large [61].

\section{Characteristics of respondents}

The majority of respondents were mainly rural dwellers (63\%), aged between 18 to 27 years $(54 \%)$, had been using the government website for a maximum of 4 years (47\%), studied up to a bachelor degree as their highest qualification level $(40 \%)$, worked in the private sector (53\%), had an account on the government e-portal $(62 \%)$ and used the government website less than once a month $(32 \%)$. The fact that this sample contained mostly educated citizens and few people who were aged above 51 years, reflects what other studies have reported, that is, internet and e-government users tend to be young and literate [5, 50, 62, 63]. It is hard for the elderly to learn how to use technology and software [64]. The higher percentage of rural users in the sample may be due to the fact that rural dwellers are more likely to use the Mauritian government website than urban dwellers as reported previously by [65]. Also the majority of the sample consists of women which are similar to the official female population (50.6\%) in Mauritius [66]. This sample is a national representative of Mauritians e-government users.

Table 1: Characteristics of participants

\begin{tabular}{|c|c|c|c|}
\hline Factors & Categories & Frequency & Percentage \\
\hline \multirow{2}{*}{ Gender } & Men & 109 & 49.3 \\
\hline & Women & 112 & 50.7 \\
\hline \multirow{2}{*}{$\begin{array}{l}\text { Area of } \\
\text { residence }\end{array}$} & Rural & 140 & 63.3 \\
\hline & Urban & 81 & 36.7 \\
\hline \multirow{5}{*}{ Age group } & 18 to 27 years & 119 & 53.8 \\
\hline & 28 to 39 years & 72 & 32.6 \\
\hline & 40 to 50 years & 24 & 10.9 \\
\hline & 51 to 62 years & 5 & 2.3 \\
\hline & Above 62 years & 1 & 0.5 \\
\hline \multirow{4}{*}{$\begin{array}{l}\text { User } \\
\text { experience } \\
\text { with the } \\
\text { government } \\
\text { website }\end{array}$} & Less than 1 year & 57 & 25.8 \\
\hline & Up to 4 years & 103 & 46.6 \\
\hline & Up to 8 years & 44 & 19.9 \\
\hline & Less than 15 years & 17 & 7.7 \\
\hline \multirow{5}{*}{$\begin{array}{l}\text { Highest } \\
\text { qualificatio } \\
\mathrm{n}\end{array}$} & 'O' level & 24 & 10.9 \\
\hline & 'A' level & 53 & 24.0 \\
\hline & Diploma & 31 & 14.0 \\
\hline & Bachelor degree & 89 & 40.3 \\
\hline & $\begin{array}{l}\text { Postgraduate } \\
\text { degree }\end{array}$ & 24 & 10.9 \\
\hline \multirow[b]{3}{*}{$\begin{array}{l}\text { Sector of } \\
\text { occupation }\end{array}$} & Private sector & 117 & 52.9 \\
\hline & Public sector & 82 & 37.1 \\
\hline & $\begin{array}{l}\text { Others (for e.g. } \\
\text { housewives, the } \\
\text { unemployed and } \\
\text { sick) }\end{array}$ & 22 & 10.0 \\
\hline \multirow{5}{*}{$\begin{array}{l}\text { Frequency } \\
\text { of use }\end{array}$} & $\begin{array}{l}\text { Less than once a } \\
\text { month }\end{array}$ & 71 & 32.1 \\
\hline & $\begin{array}{l}\text { At least once a } \\
\text { month }\end{array}$ & 48 & 21.7 \\
\hline & $\begin{array}{l}\text { At least once a } \\
\text { fortnight }\end{array}$ & 36 & 16.3 \\
\hline & $\begin{array}{l}\text { At least once a } \\
\text { week }\end{array}$ & 42 & 19.0 \\
\hline & At least once a day & 24 & 10.9 \\
\hline Sample size & $\mathrm{N}$ & 221 & 100 \\
\hline
\end{tabular}




\section{E. Research Hypothesis}

After carrying out an intensive literature and empirical review, the following hypotheses were formulated to investigate into the factors that determine the continued use of the government website in Mauritius:

H1. Performance expectancy positively influences the continued use of the Mauritian government website.

H1a. Demographic factors affect items under performance expectancy

H1b. Website-related factors affect items under performance expectancy

$\mathrm{H} 2$. Effort expectancy positively influences the continued use of the Mauritian government website.

H2a. Demographic factors affect items under effort expectancy

$\mathrm{H} 2 \mathrm{~b}$. Website-related factors affect items under effort expectancy

H3. Facilitating conditions positively influence the continued use of the Mauritian government website

H3a. Demographic factors affect items under facilitating conditions

H3b. Website-related affect items under facilitating conditions

H4. Social influence positively affects the continued use of the Mauritian government website.

H4a. Demographic factors affect items under Social influence

H4b. Website-related factors affect items under Social influence

H5. Trust positively influences the continued use of the Mauritian government website.

H5a. Demographic factors affect items under Trust.

H5b. Website-related factors affect items under Trust.

\section{ANALYSIS \& DISCUSSION}

\section{A. Performance Expectancy and the use of government website in Mauritius}

\section{H1: Performance expectancy positively influences the} continued use of the Mauritian government website

Kruskal-Wallis $\mathrm{H}$ tests are conducted for each item under the performance expectancy component and behavioural intention. Key performance expectancy determinants of e-government use in the short and long run are the extent to which an individual believes that the website is useful, contains the required services, allows task completeness and improves his/her job performance. Although an updated website does not predict e-government use over the next 3 months, it is a significant determinant of continuous e-government use in the future. Table 2 highlights the findings.

\section{Hla. Demographic factors affect items under performance expectancy}

Mann-Whitney U tests were used to assess the impacts of gender and urbanisation on those items under performance expectancy that eventually predict behavioural intention. Neither gender nor urbanisation affects citizens' perceptions on performance expectancy. Jonckheere-Terpstra test also revealed no statistical significant influence of education on performance expectancy.

Jonckheere-Terpstra test was conducted to assess the impact of age on performance expectancy. Age group does not affect performance expectancy with the exception of the item 'The government website helps me to improve my job performance'. The older an individual gets, the stronger is his/her belief that the use of government website will improve his/her job performance $\left(\mathrm{T}_{\mathrm{JT}}=8377, \mathrm{Z}=2.599\right.$, $\mathrm{r}=0.175, \mathrm{p}=0.003)$. This suggests that older citizens in Mauritius do not have computer fear and are aware of the information available on the government e-portal.

Kruskal-Wallis $\mathrm{H}$ tests showed that sector of occupation did not influence any item under performance expectancy except for 'The government website helps me to improve my job performance' $[\mathrm{H}(2)=30.172, \mathrm{p}=0.000]$. Two Mann-Whitney U tests were done to find out which sectors of occupation. In an attempt not to inflate Type 1 error rate, the Bonferroni correction was applied. The results show that citizens employed in the public sector had higher claims of improved job performance due to their e-government use than those employed in the private sector $(\mathrm{U}=2756$, $\mathrm{Z}=-5.321, \mathrm{r}=-0.377, \mathrm{p}=0.000)$ and described as 'others' $(\mathrm{U}=531, \mathrm{Z}=-\mathrm{-3} .145, \mathrm{r}=-0.308, \mathrm{p}=0.002)$.

The effect of age on the items affecting the continued use of government website in Mauritius was small but the effect of sector of occupation was medium.

\section{H1b. Website-related factors affect items under performance expectancy}

Jonckheere-Terpstra test were conducted to examine the impacts of frequency of e-government use and user experience on performance expectancy. User experience only affects the item 'I find the government website useful' under the performance expectancy component. The more experienced the user was, the more he/she described it as being useful $\left(\mathrm{T}_{\mathrm{JT}}=9026, \mathrm{Z}=1.814, \mathrm{r}=0.122, \mathrm{p}=0.035\right)$.

Moreover the higher the frequency of e-government use,

- the more useful individuals found the website to be $\left(\mathrm{T}_{\mathrm{JT}}\right.$ $=10039, \mathrm{Z}=1.931, \mathrm{r}=0.130, \mathrm{p}=0.03$ ),

- the higher was their job performance $\left(T_{\mathrm{JT}}=11560\right.$, $\mathrm{Z}=4.099, \mathrm{r}=0.276, \mathrm{p}=0.000$ ) and

- the higher number of tasks they could accomplish through the government website $\left(\mathrm{T}_{\mathrm{JT}}=10402\right.$, $\mathrm{Z}=1.921, \mathrm{r}=0.129, \mathrm{p}=0.029)$.

However small changes in usefulness of website, task completion and job performance were noted across the different groups of e-government users. 


\section{Predicting E-Government Use in Mauritius: Non-Parametric Procedures}

\section{B. Effort Expectancy and the use of government website in Mauritius}

\section{H2: Effort expectancy positively influences the continued use of the Mauritian government website}

Kruskal-Wallis $\mathrm{H}$ tests are conducted for each item under the effort expectancy component and behavioural intention. Items under effort expectancy that predict behavioural intention in the short run are the extent to which a citizen finds what he/she is looking for and how convenient it is for him/her to access the government website. Key long term determinants are the extent to which the website is easy to use and understand; and the ease of finding information online.

\section{H2a. Demographic factors affect items under Effort expectancy}

None of the items under effort expectancy were influenced by education level and urbanisation.

Mann-Whitney $U$ tests revealed that gender has a significant effect only on the item 'It is easy to get what I am looking for on the government website' ( $U=5322, \mathrm{Z}=-1.789$, $\mathrm{r}=-0.120, \mathrm{p}=0.038)$ and women have a higher mean rank compared to men. These imply that women found it easier than men to get the information they were seeking online.

Jonckheere-Terpstra test revealed that age had significant and negative effects on one item under effort expectancy: 'The government website is easy to use' $\left(\mathrm{T}_{\mathrm{JT}}=6342\right.$, $\mathrm{Z}=-1.900, \mathrm{r}=-0.128, \mathrm{p}=0.027)$. The older the citizens were, the more difficult it was for them to use the government website.

Sector of occupation, as revealed by the Kruskal-Wallis $\mathrm{H}$ test, influenced users' perceptions of two items under effort expectancy: 'It is easy to get what I am looking for on the government website' $[\mathrm{H}(2)=7.738, \mathrm{p}=0.021]$ and 'The government website is easy to use' $[\mathrm{H}(2)=6.843, \mathrm{p}=0.033]$. Two Mann-Whitney U tests were done for each item as follow up. Eventually the Bonferroni correction was applied so to keep Type 1 error below 0.05 and the critical level of significance was 0.025 instead of 0.05 . Firstly, public sector employees and private sector employees were no different when it was about the ease of getting what they were seeking on the government website. However the ease of getting what was sought online differed between public sector employees and 'others' where the former found it much easier to get what they were looking for $(\mathrm{U}=597.5, \mathrm{Z}=-2.641$, $\mathrm{r}=-0.259, \mathrm{p}=0.008$ ). Secondly there was no significant difference between public sector employees and private sector employees about the ease of using the government website. But public sector employees found it much easier to use the government website than those citizens falling into the 'others' category $(\mathrm{U}=624.5, \quad \mathrm{Z}=-2.522, \quad \mathrm{r}=-0.247$, $\mathrm{p}=0.012$ ). This may be due to their frequent use of the government website and the training that they might have undergone in the government offices.

Gender, age and sector of occupation exerted small effects on the determinants of e-government use in Mauritius.

\section{H2b. Website-related factors affect items under Effort} expectancy

Jonckheere-Terpstra tests were conducted to examine the effects of user experience and frequency of e-government use on effort expectancy.

It was found that frequency of e-government use affects three items under effort expectancy. These are displayed in Table 3. The more often a citizen used the government website,

- the easier it was for him/her to get what he/she was looking for (TJT =10506, $\mathrm{Z}=2.233, \mathrm{r}=0.15$, $\mathrm{p}=0.012$ ),

- the more comprehensible the website was to him/her $(\mathrm{TJT}=10637, \mathrm{Z}=2.539, \mathrm{r}=0.171, \mathrm{p}=0.006)$ and

- the easier it was for him/her to use the website (TJT $=10428, \mathrm{Z}=2.096, \mathrm{r}=0.141, \mathrm{p}=0.019$ ).

User experience however did not affect any of the items under the effort expectancy component. As argued by Taylor and Todd [67], citizens with experience might have already overcome their concerns about ease of use and might be emphasising more on the usefulness of the government website. This holds true for the item 'The government website is useful' in Table 3 where user experience was a significant influence on performance expectancy. Moreover experienced users have greater satisfaction [68] and do not necessarily determine the continued use of e-government.

Frequency of e-government use had a small effect on the determinants of behavioural intention.

\section{Facilitating Conditions and the use of government website in Mauritius}

\section{H3: Facilitating conditions positively influence the} continued use of the Mauritian government website

Kruskal-Wallis $\mathrm{H}$ tests are conducted for each item under the facilitating condition component and behavioural intention. Significant short and long term determinants under the 'facilitation conditions' component include self-efficacy items such as having adequate knowledge; feeling confident about the use of government website; the extent to which its use fits into citizens' daily lives and the extent to which e-government use is supported at workplace. Other factors that are not statistically significant in the long run but determine the use of government website over the next 3 months are internet subscription rates and access to the Mauritian government website through a personal computer/laptop. Table 4 summarises the results.

\section{H3a. Demographic factors affect items under} facilitating conditions

Age and urbanisation do not predict any item under the facilitating condition component.

Mann-Whitney $U$ tests did not yield significant differences across the perceptions of men and women except for one item: 'My workplace supports the use of government website' ( $\mathrm{U}=5170, \mathrm{Z}=-2.064, \mathrm{r}=-0.139$, $\mathrm{p}=0.037)$. Women tended to claim more than men that their workplace encouraged e-government use. The effect of having workplace support on women compared

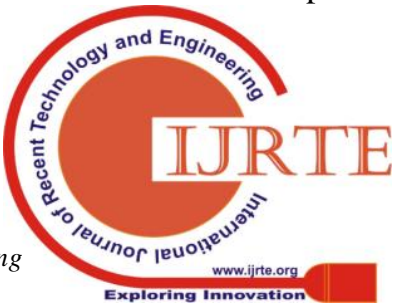


to men however was small.

Jonckheere-Terpstra test was done to examine the effect of rising education level on citizens' perceptions on the facilitating condition component. It was revealed that education only affects two items: 'I have access to the government website from my PC/Laptop' $\left(\mathrm{T}_{\mathrm{JT}}=10704\right.$, $\mathrm{Z}=3.664, \mathrm{r}=0.246, \mathrm{p}=0.000$ ) and 'My workplace supports the use of government website' $\left(\mathrm{T}_{\mathrm{JT}}=10081, \mathrm{Z}=2.164\right.$, $\mathrm{r}=0.146, \mathrm{p}=0.015)$. As citizens acquired more education,

- they increasingly accessed the government website through their PC or laptops and

- they increasingly claimed that their workplace supported the use of government webpages.

Some Kruskal-Wallis $\mathrm{H}$ tests were done to study the effect of sector of occupation on facilitating conditions. However only one item was statistically significant: 'My workplace supports the use of government website' $[\mathrm{H}(2)=31.513$, $\mathrm{p}=0.000]$. Two Mann-Whitney $U$ tests were done as followed up to identify which sectors differed. Those e-government users who worked in the private sector $(\mathrm{U}=2759, \mathrm{Z}=-5.372, \mathrm{r}=-0.381, \mathrm{p}=0.000)$ or were described as 'others' $(U=491, Z=-3.510, r=-0.344, p=0.000)$ were statistically different from public sector employees. The latter made higher claims about the support received at work for the use of government website.

However the effects of gender and education on the predictors of e-government use in Mauritius were small whereas sector of occupation exerted a medium effect on those predictors.

\section{H3b. Website-related factors affect items under facilitating conditions}

Jonckheere-Terpstra tests were conducted to study the effects of frequency of e-government use and user experience on items under facilitating conditions. Frequency of website use affected two items: 'Use of the government website fits into my daily life' $\left(\mathrm{T}_{\mathrm{JT}}=11290, \mathrm{Z}=3.591, \mathrm{r}=0.242, \mathrm{p}=0.000\right)$ and 'My workplace has supported the use of government website' $\left(T_{\mathrm{JT}}=11502, \mathrm{Z}=4.011, \mathrm{r}=0.270, \mathrm{p}=0.000\right)$. These imply that as frequency of use increased, people stated more and more that the use of the government website fitted their daily lives and that their workplace supported its use.

None of the items under facilitating conditions were statistically significant when tested for differences in perceptions by the user's experience of the website except for the item, 'I have the required knowledge to use the government website' $\left(\mathrm{T}_{\mathrm{JT}}=7440, \mathrm{Z}=-1.721, \mathrm{r}=-0.116\right.$, $\mathrm{p}=0.043$ ). The higher the number of years the user had been using the website, the lower was his/her claim of being adept at using it. This may be due to the evolution of an increasingly complex government website over the years.

Effects of frequency of e-government use and user experience on the significant determinants of e-government use were small.
Table 2: Items under Performance Expectancy component

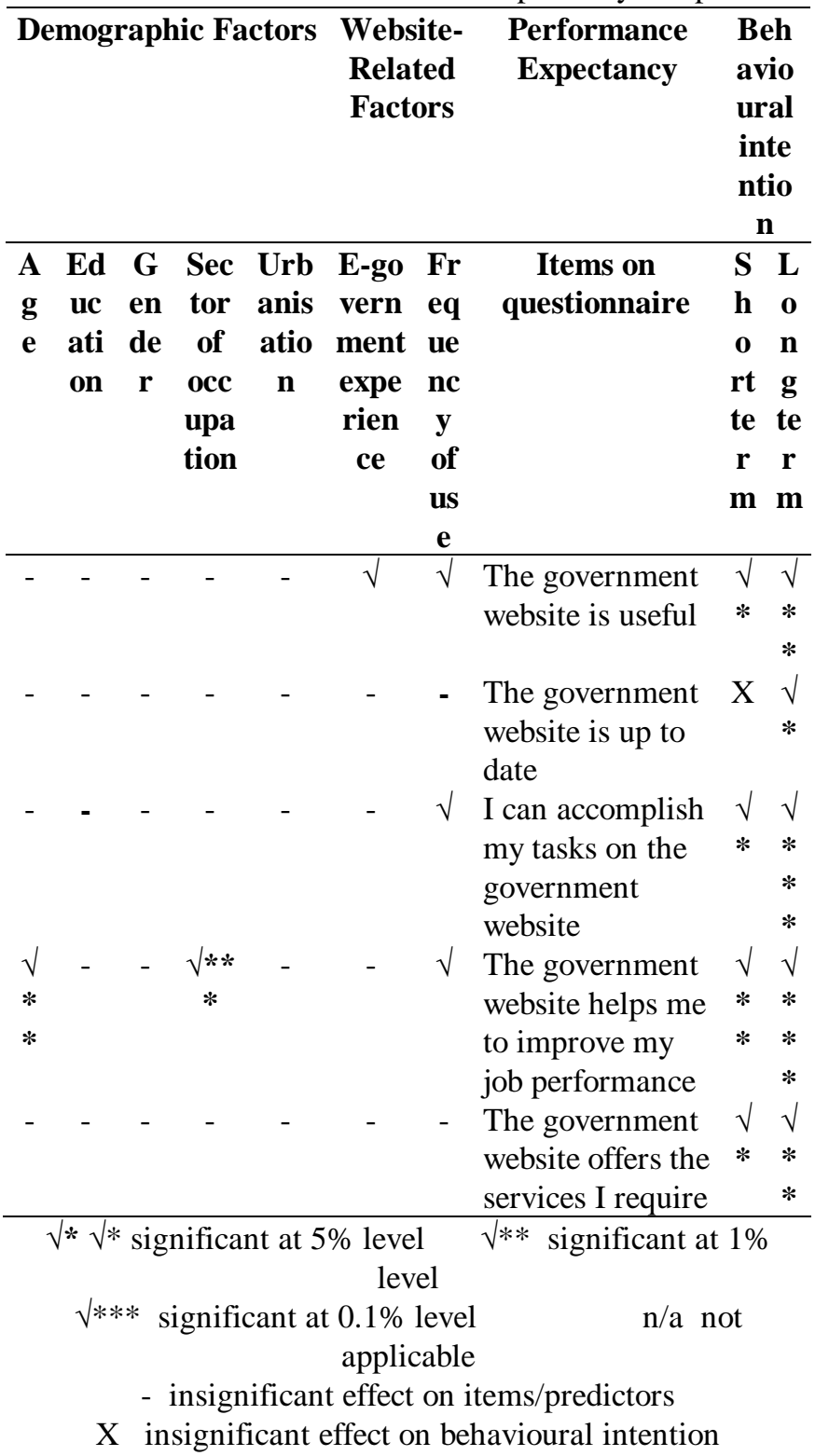

Table 3: Items under Effort Expectancy component

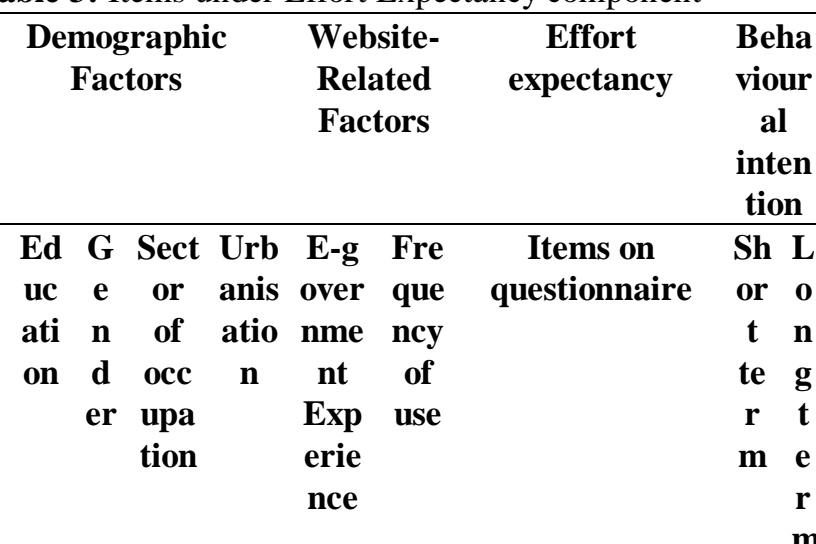

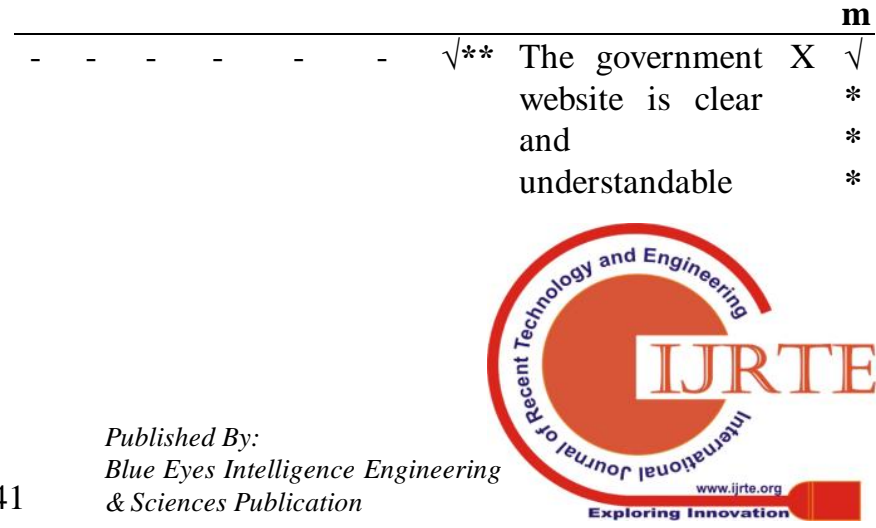




\section{Predicting E-Government Use in Mauritius: Non-Parametric Procedures}

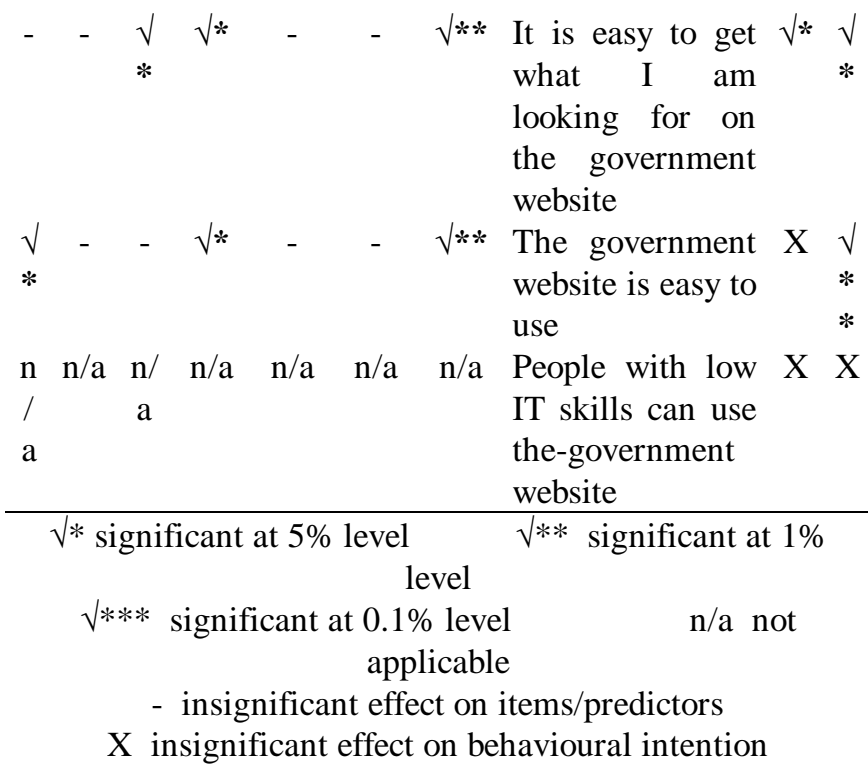

\section{Social Influence and the use of government website in Mauritius}

H4: Social influence positively affects the continued use of the Mauritian government website

Social factors as explained by Triandis [69] are the internalisation of messages received from members of a group and what individuals think they should do in certain situations. Thus the items displayed in Table 5 were included in the questionnaire. Kruskal-Wallis $\mathrm{H}$ tests are conducted for each item under the social influence component and behavioural intention. Key short and long term social influence determinants are the extent to which citizens believe that people who are important to them, who are influential and whose opinions they value would like them to use e-government. However the urge to be seen as competent by one's colleagues is also a long term predictor of continuous e-government use. These indicate the positive influence of social influence on behavioural intention. Similar finding was reported for the adoption of electronic government in Oman [70]. Family, peers and friends exerted pressures on the individual to use e-government. Table 5 summarises the results.

\section{H4a. Demographic factors affect items under Social influence}

Mann-Whitney $\mathrm{H}$ tests showed that gender significantly affected only one item under the social influence component: 'People whose opinions I value tell me to use the government website' $(\mathrm{U}=5179, \mathrm{Z}=-2.060, \mathrm{r}=-0.139, \mathrm{p}=0.04)$. Men had higher mean ranks compared to women. In other words, men agreed more than women that people whose opinions they valued, had told them to use the government website. This suggests that compared to women, men are relatively more influenced by the opinions of others.

Results from Jonckheere-Terpstra tests suggested that neither age nor education level was a significant factor in explaining social influence on an individual. None of the items under the social influence component could be influenced by age and education. Similar finding is reported for urbanisation following a Mann-Whitney $\mathrm{H}$ test to assess the impact of urbanisation on items under the social influence component.

Kruskal-Wallis $\mathrm{H}$ test revealed that sector of occupation had a significant influence on two items: "If I use the government website my colleagues will think that I am competent' $[\mathrm{H}(2)=9.770, \mathrm{p}=0.008]$ and 'People who influence my behaviour tell me to use the government website' $[\mathrm{H}(2)=9.837, \mathrm{p}=0.007]$. Two Mann-Whitney U tests were conducted for each item in order to determine in which sectors perceptions of employees differed. It was found that both perceptions about both items differed between public sector employees and private sector employees. Given the higher mean ranks on each item for public sector employees, it may be deduced that their use of the government website was relatively more influenced by people ( $\mathrm{U}=3635, \mathrm{Z}=-3.037, \mathrm{r}=-0.215, \mathrm{p}=0.003)$ and due to their need of being seen as competent by their colleagues ( $\mathrm{U}=3634, \mathrm{Z}=-3.135, \mathrm{r}=-0.222, \mathrm{p}=0.002$ ). However the perceptions of public sector employees and those of the group described as 'others' were not statistically different for each item.

The effects of gender and sector of occupation on the determinants of e-government use were small.

H4b. Website-related factors affect items under Social influence

To assess the impacts of website-related factors on items within the social influence component, a few Jonckheere-Terpstra tests were done. Frequency of e-government use however has significant effects on 3 items: 'If I use the government website my colleagues will think that I am competent' $\left(\mathrm{T}_{\mathrm{JT}}=11002.5, \mathrm{Z}=3.016, \mathrm{r}=0.203\right.$, $\mathrm{p}=0.002$ ), 'People who influence my behaviour tell me to use the government website' $\left(\mathrm{T}_{\mathrm{JT}}=10526, \mathrm{Z}=2.136, \mathrm{r}=0.144\right.$, $\mathrm{p}=0.018$ ) and 'People whose opinions I value tell me to use the government website' $\left(\mathrm{T}_{\mathrm{JT}}=10487.5, \mathrm{Z}=2.029\right.$, $\mathrm{r}=0.136$, $\mathrm{p}=0.019$ ). The higher the frequency of e-government use,

- the higher were claims by users that people whose opinions they valued, had told them to do so

- the more users stated that their decision to use the government website was increasingly due to people who had influenced them and

- the stronger were their beliefs that the use of the government website made their colleagues perceived them as being competent.

User experience with the government website significantly affected only one item, 'If I use the government website, my colleagues will think that I am competent' $\left(\mathrm{T}_{\mathrm{JT}}\right.$ $=6931.5, \mathrm{Z}=-2.566, \mathrm{r}=-0.173, \mathrm{p}=0.004)$. This implies that more experienced users had weaker beliefs that e-government use would make their colleagues see them as being competent. This may be attributed to the fact that their colleagues were also using the government website and were equally good at its use. 
However the effects of frequency of e-government use and user experience on the predictors of e-government use were small.

\section{E. Trust and the use of government website in Mauritius}

H5: Trust positively influences the continued use of the Mauritian government website

Kruskal-Wallis $\mathrm{H}$ tests are conducted for each item under the trust component and behavioural intention. Significant short and long term predictors of the 'Trust' dimension include items such as feeling secure to reveal personal information online, belief that such information will not be divulged to malicious third parties, reliability of the website and government departments. Items that do not affect a citizen's decision in the short run but play significant roles in their decisions to continue to use the government website in the future are the enactment of laws against cybercrimes and maintaining the confidentiality of information keyed online by citizens. Table 6 displays all results.

Although it is easier today to find citizens who use government website in Mauritius many of them do not make payment online. Only $9.6 \%$ used the government e-portal to make payment online and this is in line with the findings of Ponte, Carvajal-Trujillo [55] who reported that inadequate perceived privacy and security protection in e-commerce caused people not to transact online. Around $49 \%$ of the sample stated that they would never insert details of their debit or credit cards online whereas some of the respondents who stated the contrary would do so because they anticipated a refund from the Mauritius Tax Revenue Authority. For many users online payments are not traceable and they would not know where to retrieve them. Nevertheless as reported in Table 6 readiness to insert details of debit/credit cards does not predict the use of the Mauritian government website at all.

Also around $57 \%$ of the sample stated that they did not feel secure to disclose their personal details on government e-portal. This is in line with the fear of identity theft if all citizen information is kept in a central e-registry. This fear may be overcome if citizens are reassured that all their information will be protected against misuse by third parties and unscrupulous government officials. Security concerns are important barriers to the use of technology [71] and may explain why Mauritians use the government website mainly for looking up information, downloading forms and submitting requests online instead of making payments online. If safeguards are in place, Mauritian citizens would be willing to take the risk, for example, $47.7 \%$ of the sample stated that laws against cybercrimes would convince them to reveal confidential information on the government website.

Table 4: Items under Facilitating Condition component

\begin{tabular}{|c|c|c|c|c|c|c|c|}
\hline & Demog & aphic & ctors & $\begin{array}{l}\text { V } \\
-1 \\
\text { F }\end{array}$ & $\begin{array}{l}\text { Website } \\
\text {-Related } \\
\text { Factors }\end{array}$ & $\begin{array}{l}\text { Facilita } \\
\text { ting } \\
\text { Conditi } \\
\text { ons }\end{array}$ & $\begin{array}{c}\text { Behav } \\
\text { ioural } \\
\text { intent } \\
\text { ion } \\
\end{array}$ \\
\hline g & $\begin{array}{ll}\text { Edu } & \text { Ge } \\
\text { cati } & \text { nd }\end{array}$ & or of & nisati & $\begin{array}{l}\text { E-go } \\
\text { ernm }\end{array}$ & $\begin{array}{ll}\text { ov } & \text { Freq } \\
\text { m } & \text { uenc }\end{array}$ & $\begin{array}{l}\text { Items } \\
\text { on }\end{array}$ & $\begin{array}{ll}\text { Sh } & L \\
\text { or } & \text { on }\end{array}$ \\
\hline
\end{tabular}

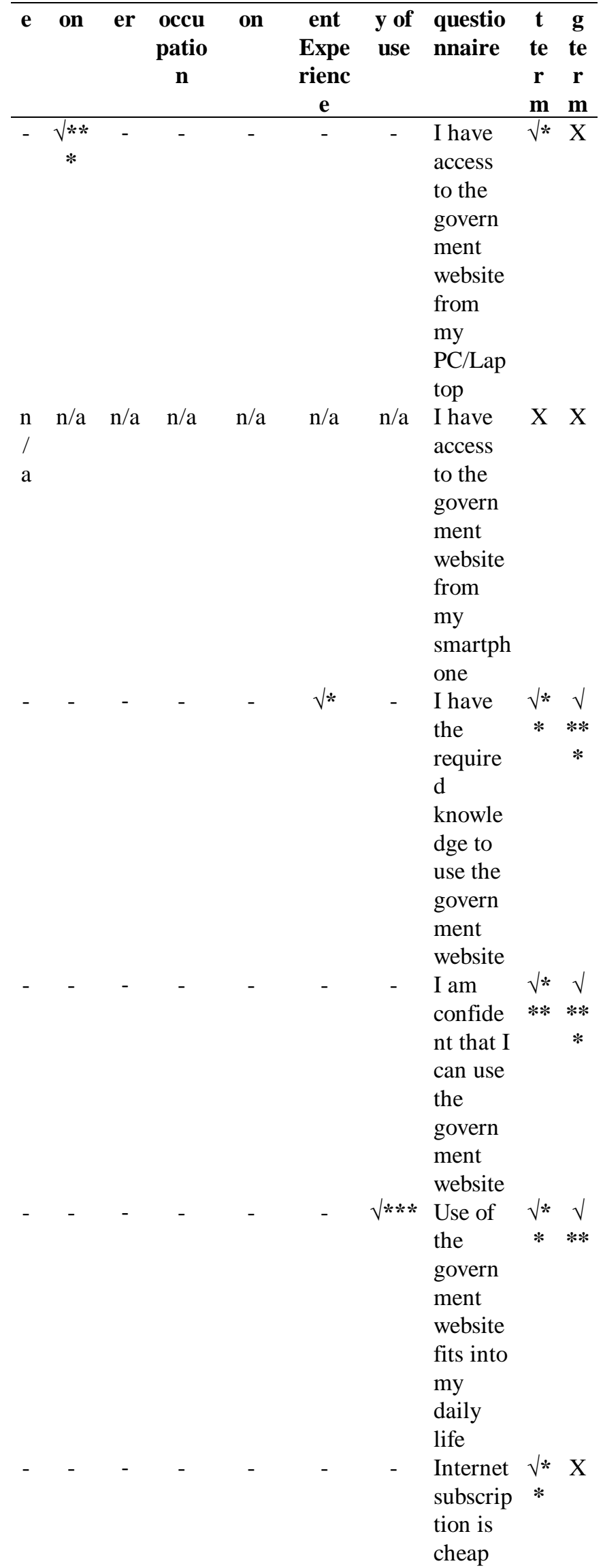




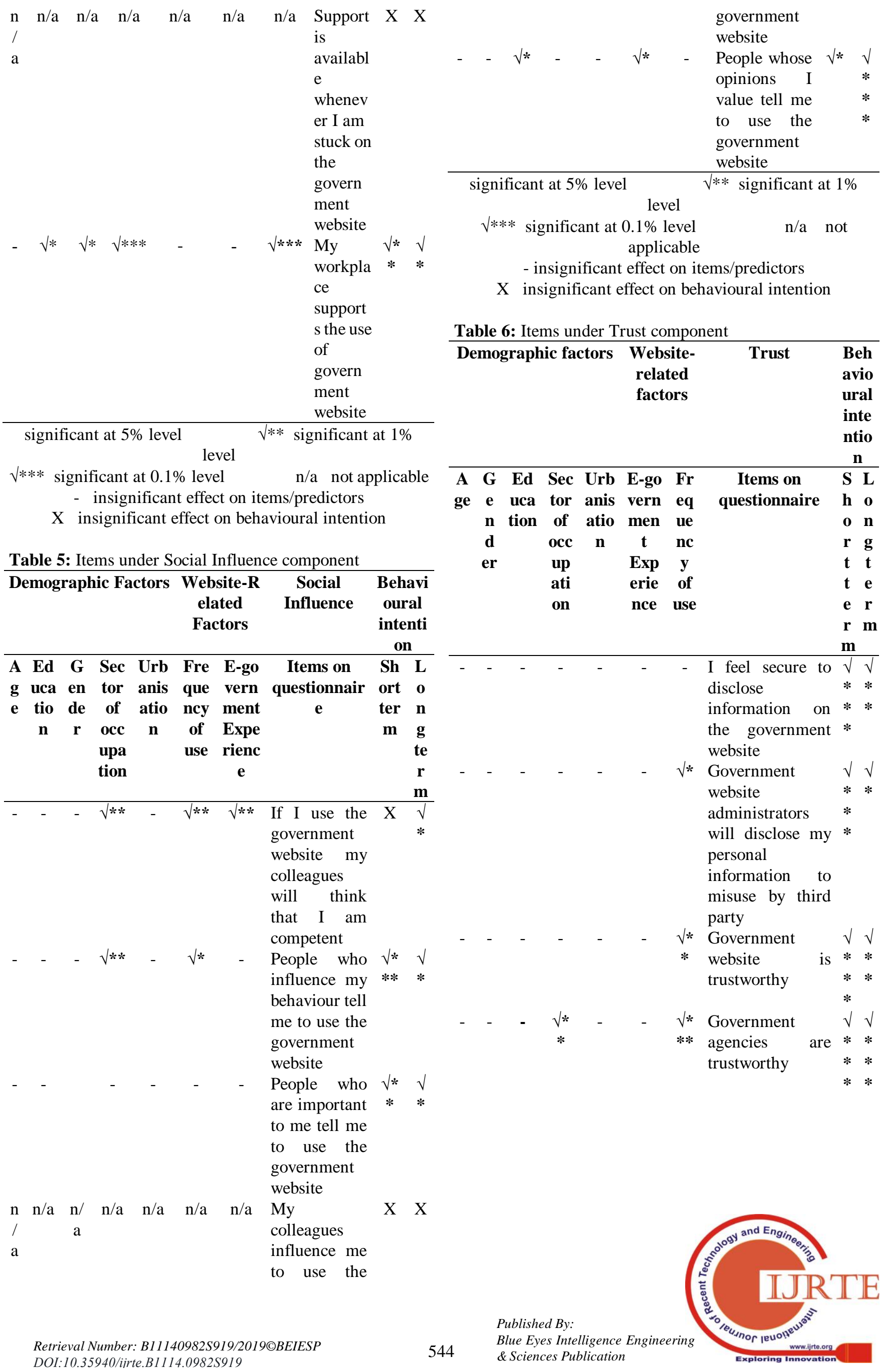




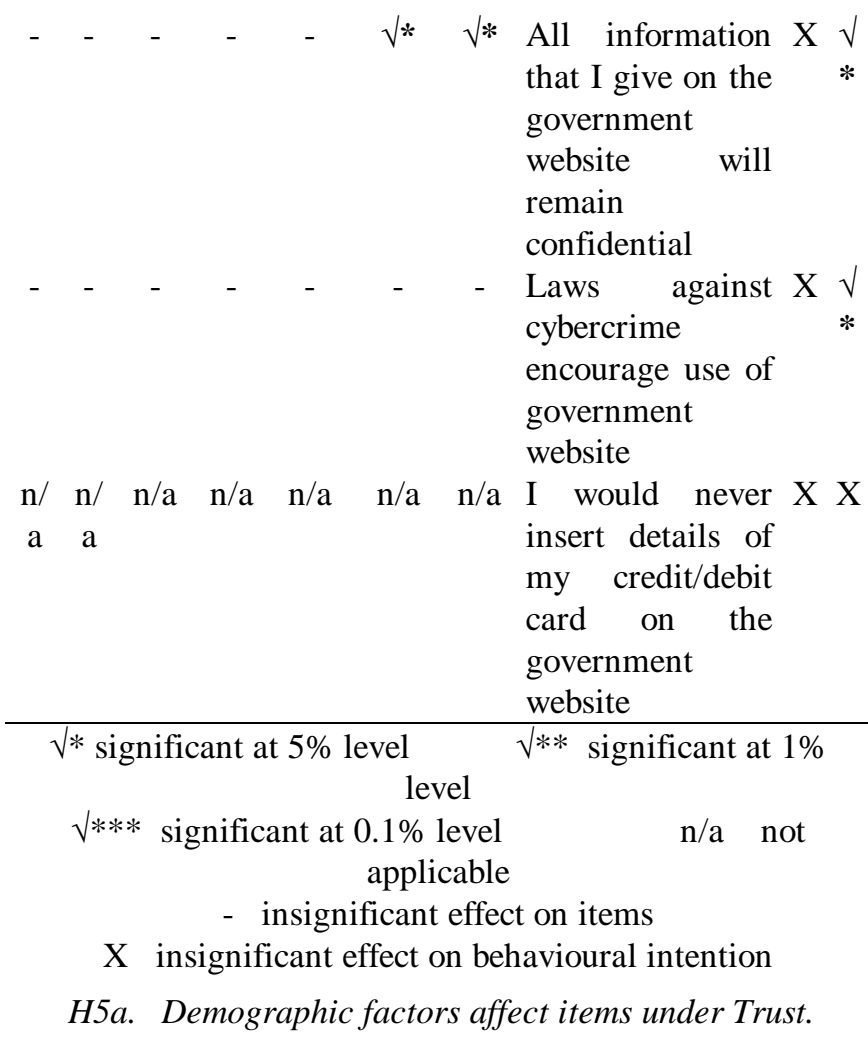

Gender, urbanisation, age and education do not affect any item under the trust dimension. Mann-Whitney U tests did not reveal any significant difference in the perceptions of men and women towards trust and no significant difference was found in the perceptions of urban and rural dwellers towards trust. As per Jonckheere-Terpstra tests age and education also did not influence citizens' perceptions of trust.

Sector of occupation however affected one item under the trust dimension, 'Government agencies are trustworthy' $[\mathrm{H}(2)=9.189, \mathrm{p}=0.01]$. After the Bonferroni correction and two Mann-Whitney U tests, it was found that the significant difference lied between the perceptions of public and private employees $(\mathrm{U}=3727, \mathrm{Z}=-2.797, \mathrm{r}=-0.198, \mathrm{p}=0.005)$ where e-government users employed in the public sector believed in government agencies more those employed in the private sector. This may be attributed to the loyalty and fear towards their boss or to the fact that they know how secure government agencies are. Effect of sector of occupation on the predictor of e-government use under the trust dimension was however small.

\section{H5b. Website-related factors affect items under Trust.}

However a few Jonckheere-Terpstra tests indicated that frequency of government website use positively affected four items: 'Government website administrators will disclose my personal information to misuse by third party' $\left(\mathrm{T}_{\mathrm{JT}}\right.$ $=10396.5, \quad \mathrm{Z}=1.827, \quad \mathrm{r}=0.123, \mathrm{p}=0.035)$, 'Government website is trustworthy' $\left(\mathrm{T}_{\mathrm{JT}}=10920, \mathrm{Z}=2.865, \mathrm{r}=0.193\right.$, $\mathrm{p}=0.002)$, 'Government agencies are trustworthy' $\left(\mathrm{T}_{\mathrm{JT}}\right.$ $=11098.5, \quad \mathrm{Z}=3.205, \quad \mathrm{r}=-0.216, \quad \mathrm{p}=0.000$ ) and 'All information that I give on the government website will remain confidential' $\left(\mathrm{T}_{\mathrm{JT}}=10524, \mathrm{Z}=2.086, \mathrm{r}=-0.140\right.$, $\mathrm{p}=0.017$ ). It may therefore be deduced that increased frequency of use strengthened citizens' beliefs that
- government officials would not give out their personal information to others for misuse

- the government website and departments were reliable

- citizens' personal information inserted on the government website would remain confidential.

User's experience of the government website did not affect items under the trust dimension except for one item: 'All information that $\mathrm{I}$ give on the website will remain confidential' $\left(\mathrm{T}_{\mathrm{JT}}=7172.5, \mathrm{Z}=-2.083, \mathrm{r}=-0.140, \mathrm{p}=0.021\right)$. User experience thus significantly and negatively affected citizens' belief about the discretion of the government website. More experienced users (regular users) of e-government services had weaker beliefs that their information would remain confidential. This might suggest previous bad experiences with the government website or any other online transaction form other vendors or an increasing awareness of the existence of hackers especially during monetary transactions.

Effects of all relevant website-related factors on the predictors of e-government use under the trust dimension were however small.

\section{F. Overall impacts of factors on determinants of e-government in Mauritius}

The performance expectancy component is basically influenced by the frequency of e-government use such that regular users tend to attribute higher performance gains to the government website. However neither demographic nor website-related factors affected citizens' perceptions on whether the government website was updated and whether it offered the services they required. Around $52 \%$ of the sample did not describe the website as being up to date but around $50 \%$ stated that it offered the services they required. Their continued use of the government website may therefore be explained by their need to get what they require and the absence of alternatives in the provision of public services.

Most items under the effort expectancy component were most influenced by frequency of e-government use, followed by sector of occupation, gender and age. Higher frequency of use was associated with less effort to use the government website. Public sector employees, women and the youngest users also made the least effort to use e-government compared to their counterparts. Under the social influence component, men and inexperienced users were more influenced by others to use the government website. Similarly regular users and public sector employees were more influenced by their peers, friends and family.

Frequency of e-government use and education level affected most items under the facilitating components. Regular and more educated users had more infrastructure and support to use the government website. But none of the demographic and website-related factors influence citizens' perceptions on how confident they are and how costly it is for them to use the government website. These may reflect their need to subscribe to the internet irrespective of whether or not they access the government website and they draw their confidence from

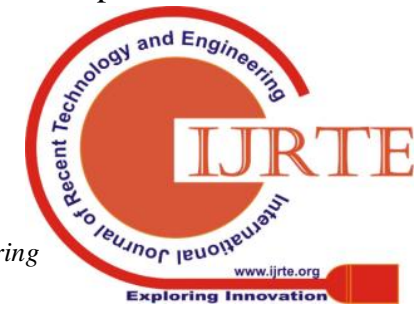


their environment, for example from people surrounding them from whom they would usually seek help.

It may be argued that the Trust component is primarily influenced by frequency of e-government use where regular users tended to show greater trust in the government website. However there were no demographic and website-related factors that could significantly influence citizens' perceptions of how secure it was for them to disclose information and whether enacting laws against cybercrime would encourage them to continue to use the government website. Around $55 \%$ of the sample had disagreed that it was secured to disclose information which may be attributed to the recent leakage of personal details of Mauritians that was given at the time of renewal of national identity cards. Around 22\% expressed no opinion on whether laws would safeguard them once they input their details on the government website. Some of them stated that they were not sure how the law would protect them. Thus it is important to explain to citizens how the law works in their favour and how online payments and its process may be safe and retrieved.

Table 7: Overall effect sizes of demographic and website-related factors on modified UTAUT model

\begin{tabular}{|c|c|c|c|c|c|}
\hline & $\begin{array}{c}\text { Performa } \\
\text { nce } \\
\text { expectanc } \\
y\end{array}$ & $\begin{array}{c}\text { Effort } \\
\text { expecta } \\
\text { ncy }\end{array}$ & $\begin{array}{c}\text { Facilitat } \\
\text { ing } \\
\text { conditio } \\
\text { n }\end{array}$ & $\begin{array}{c}\text { Social } \\
\text { influen } \\
\text { ce }\end{array}$ & $\begin{array}{c}\text { Tru } \\
\text { st }\end{array}$ \\
\hline Age & $\begin{array}{l}\text { Small } \\
\text { effect }\end{array}$ & $\begin{array}{l}\text { Small } \\
\text { effect }\end{array}$ & & & \\
\hline Education & & & $\begin{array}{l}\text { Small } \\
\text { effect }\end{array}$ & & \\
\hline Gender & & $\begin{array}{l}\text { Small } \\
\text { effect }\end{array}$ & $\begin{array}{l}\text { Small } \\
\text { effect }\end{array}$ & $\begin{array}{l}\text { Small } \\
\text { effect }\end{array}$ & \\
\hline $\begin{array}{l}\text { Sector of } \\
\text { Occupatio } \\
n\end{array}$ & $\begin{array}{l}\text { Medium } \\
\text { effect }\end{array}$ & $\begin{array}{l}\text { Small } \\
\text { effect }\end{array}$ & $\begin{array}{l}\text { Medium } \\
\text { effect }\end{array}$ & $\begin{array}{l}\text { Small } \\
\text { effect }\end{array}$ & $\begin{array}{l}\text { Sma } \\
\text { ll } \\
\text { effec } \\
\mathrm{t}\end{array}$ \\
\hline $\begin{array}{l}\text { Urbanisati } \\
\text { on }\end{array}$ & & & & & \\
\hline $\begin{array}{l}\text { E-govern } \\
\text { ment } \\
\text { experience }\end{array}$ & $\begin{array}{l}\text { Small } \\
\text { effect }\end{array}$ & & $\begin{array}{l}\text { Small } \\
\text { effect }\end{array}$ & $\begin{array}{l}\text { Small } \\
\text { effect }\end{array}$ & $\begin{array}{l}\text { Sma } \\
\text { ll } \\
\text { effec } \\
\mathrm{t}\end{array}$ \\
\hline $\begin{array}{l}\text { Frequency } \\
\text { of } \\
\text { e-governm } \\
\text { ent use }\end{array}$ & $\begin{array}{l}\text { Small } \\
\text { effect }\end{array}$ & $\begin{array}{l}\text { Small } \\
\text { effect }\end{array}$ & $\begin{array}{l}\text { Small } \\
\text { effect }\end{array}$ & $\begin{array}{l}\text { Small } \\
\text { effect }\end{array}$ & $\begin{array}{l}\text { Sma } \\
11 \\
\text { effec } \\
\mathrm{t}\end{array}$ \\
\hline
\end{tabular}

$\square$ Not statistically significant

Table 7 summarises the major impacts of each demographic and website-related factors on the determinants of continued e-government use in Mauritius. Frequency of e-government use and sector of occupation, especially employment in the public sector significantly affected all components of the proposed modified UTAUT model. However whether a citizen lived in a rural or urban area did not influence any of these components. E-government experience influenced all components of the modified UTAUT model except for effort expectancy.
Gender only influenced the effort expectancy, facilitating condition and social influence components. Age has a statistically significant effect on both technology attributes (PE and EE) but does not predict e-government use under the facilitating condition, social influence and trust components. Education did not affect citizens' perceptions towards the continued use of e-government except for the facilitating condition component. Almost all demographic and website-related factors exerted small effects on the components of the modified UTAUT model except for sector of occupation which had medium effects on performance expectancy and on facilitating conditions.

\section{CONCLUSION AND POLICY IMPLICATIONS}

This study changes the way in which research on e-government use has so far been conducted within the UTAUT model. It identifies all significant items behind each UTAUT core component that affect the users' decisions to continue to use the Mauritian government website.

Items that predicts citizens' intentions to continue to use the government website over both the short run and long run are availability of useful and required e-government services; ease of finding information; possibility of improving performance and ability to complete tasks online; support at work; being knowledgeable and self-confident; fitting into everyday life; recommendations from influential and important people whose opinions are valued by the particular user; online security and non-exposure of information to third party misuse; trust in government departments and website. Other items that only predict e-government use over the short term but not over the long term occur when the user owns a personal computer or laptop and has cheap internet subscription. Users' intentions to continue to use the government website in the future but not over the short term occurs when the user requires a website which is easy to understand and use; contains updated information; is protected by law and maintains confidentiality; and raises one's competency in the eyes of colleagues.

Users' perceptions about performance expectancy differed by their age groups, sector of occupation, e-government experience and frequency of e-government use. In other words older, experienced and regular e-government users; and those employed in the public sector claimed that the government website helped them to attain gains in their jobs.

Users' perceptions about effort expectancy differed by age groups, gender, sector of occupation, e-government experience and frequency of e-government use. Those who are young, have more experience with the government website, work in the public sector and are women, show greater degree of ease associated with the use of the government website.

Users' perceptions about facilitating condition varied significantly by their education level, gender, sector of occupation, e-government experience and frequency of e-government use. Those citizens who are female, more

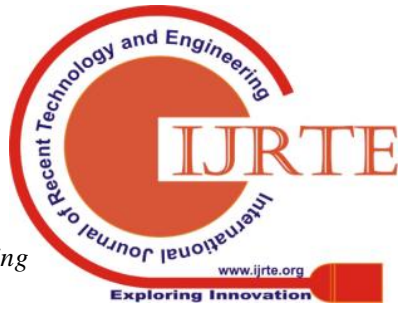


educated, employed in the public sector, have less experience with the government website and are regular users, agree to a greater extent that they have the infrastructures to support the use of the government website.

Users' perceptions about social influence differed by their gender, sector of occupation, e-government experience and frequency of e-government use. In particular men, public sector employees, regular users of the government website but with little e-government experience were more convinced by their social groups to adopt e-government.

Users' perception about trust differed significantly by their sector of occupation, e-government experience and frequency of e-government use. Regular users of the government website, public sector employees and those with little experience with the government website tend to exhibit greater trust in e-government use.

The 'Trust' dimension proposed in this research is a significant component that predicts continuous use of e-government. Winning citizens' trust means overcoming the primary huddle associated with the use of government website and conducting online transactions with the government. The government can create greater trust by improving the quality of information displayed on its website as quality is a significant determinant of trust. The website should contain authentic information [4]. Alternatively, the government website administrators should develop trust by making it easy, retraceable, safe and convenient for the user to continue his/her use of the government website

Although gender was not reported as a significant determinant of e-government use in Mauritius and elsewhere $[65,72,73]$, this research using the non-parametric approach showed its significance for the performance expectancy and trust components which ultimately predict the citizens' intentions to continue to use the Mauritian government website. Citizens' perceptions of performance expectancy, effort expectancy, social influence and trust do not differ by the highest level of education they attained. Education only has a significant effect on the facilitating condition component.

As argued by Dwivedi, Rana [74], attitudes predict behavioural intention and actual usage. Also technology attributes such as effort expectancy and performance expectancy determine both attitudes and behaviour intention. Hence the government website administrators are advised to concentrate on making the website useful and easy to use; and simultaneously enhancing user interface with clean designs.

Although e-government is supposed to bring citizens closer to the government, it may be argued that the use of technology in public administration in Mauritius is simply enabling pre-existing political and social structures without any substantial change in government-citizen relationship. This is in line with the findings of the study carried out across local governments in the European Union [75]. Moreover the risk of monopolising access to e-government by those with IT skills and social exclusion of those without IT skills must not be ignored [76].

Items under the social influence component such as recommendations from influential and important people and from people whose opinions they valued were significant in moulding behavioural intention. These imply that citizens do not only rely on other aspects of the website such as perceived usefulness but instead their behaviour is shaped by social recognition, positive reactions from others and word of mouth. However Slade, Dwivedi [77] argue that marketers should initially target innovative customers and later focus on people within their social networks.

\section{SUGGESTIONS FOR FUTURE STUDIES}

The current study is restricted to citizens' perceptions. Future studies may examine the supply side of e-government services by interviewing government website administrators and officials. Also Wirtz, Mory [78] highlighted three majors aspects: e-government information management, e-government service management and e-government interaction management that lead to overall e-government success and improved relationship between citizens and public administration. Further research could be done to examine the effects of these aspects on e-government adoption in Mauritius.

\section{ACKNOWLEDGMENT:}

I thank Miss Jessica Boyroo for collecting the majority of the data used for this study.

\section{REFERENCES}

[1] Evans D, Yen DC. E-Government: Evolving Relationship of Citizens and Government, Domestic, and International Development. Government Information Quarterly. 2006;23(2):207-35.

[2] Reffat RM. Developing A Successful E-Government. Working Paper. Sydney, Australia.2003.

[3] Huang Z. A Comprehensive Analysis of U.S. Counties' E-government Portals: Development Status and Functionalities. European Journal of Information Systems. 2007;16(2):149-64.

[4] Shampa P. A Study of E-governance Initiatives in India. The International Information and Library Review. 2007;39:176-84.

[5] Al-Shafi S, Weerakkody V, editors. Factors Affecting E-government Adoption in the State of Qatar. European and Mediterranean Conference on Information Systems, April 12-13; 2010; Abu Dhabi UAE: EMCIS2010.

[6] Venkatesh V, Morris MG, Davis GB, Davis FD. User acceptance of information technology: toward a unified view. MIS Quarterly. 2003;27(3):425-78

[7] Davis FD. Perceived usefulness, perceived ease of use, and use acceptance of information technology. MIS Quarterly. 1989;13(3):319-40.

[8] Lawson A, Willoughby L, Lawson-Body L, Tamandja EM. Students' Acceptance of E-books: An Application of UTAUT. Journal of Computer Information Systems 2018:1-12.

[9] Gruzd A, Staves K, Wilk A. Connected scholars: Examining the Role of Social Media in Research Practices of Faculty Using the UTAUT Model. Computers in Human Behavior. 2012;28(6):2340-50.

[10] San Martín M, Herrero A. Influence of the User's Psychological Factors on the Online Purchase Intention in Rural Tourism: Integrating Innovativeness to the UTAUT Framework. Tourism Management 2012;33(2):341-50.

[11] Shin D-H. Towards an Understanding of the Consumer Acceptance of Mobile wallet. Computers in Human Behavior. 2009;25(6):1343-54.

[12] Magsamen-Conrada K, Upadhyaya S, Joa CY, Dowd J. Bridging the Divide: Using UTAUT to Predict Multigenerational Tablet Adoption Practices. Computers in Human Behavior. 2015;50:186-96. 
[13] Zhou T, Lu Y, Wang B. Integrating TTF and UTAUT to Explain Mobile Banking User Adoption. Computers in Human Behavior. 2010;26(4):760-7.

[14] Chau NN, Seshadri S, Broekemier G, Pamornpathomkul S. An Exploratory Study of Mobile Shopping Behaviors of Young Adults in Thailand. Journal of Internet Commerce. 2018;17(4):339-55.

[15] Thomas TD, Singh L, Gaffar K. The Utility of the UTAUT Model in Explaining Mobile Learning Adoption in Higher Education in Guyana. International Journal of Education and Development Using Information and Communication Technology (IJEDICT). 2013;9(3):71-85.

[16] Azira EM, S, Omar SZBT. An Acceptance of 4G (Fourth Generation) Mobile Network in Malaysia. International Journal of Information and Communication Technology Research. 2013;3(8):232-7.

[17] Weerakkody V, Irani Z, LeeI H, Osman I, Hindi N. E-government Implementation: A Bird's Eye View of Issues Relating to Costs, Opportunities, Benefits and Risks. Information Systems Frontiers. 2015;17(4):889-915.

[18] Sanmukhiya C. E-governance dimensions in the Republic of Mauritius. 7th International Conference on Recent Developments in Social Sciences and Business Studies; Paya Labar Singapore2017.

[19] Belanger F, Hiller JS, Smith WJ. Trustworthiness in Electronic Commerce: The Role of Privacy, Security, and Site Attributes. Journal of Strategic Information Systems. 2002;11:245-70.

[20] Carter L, Belanger F. The utilization of e-government services: citizen trust, innovation and acceptance factors. Information Systems Journal. 2005;15(1):5-25.

[21] Rogers EM. Diffusion of Innovations. Fifth ed. New York: Free Press; 2003.

[22] Ajzen I. From Intentions to Actions: A Theory of Planned Behaviour. In: Khul J, Beckmann J, editors. Action Control: From Cognition to Behavior Berlin Heidelberg New York Tokyo: Springer-Verlag; 1985. p. 11-39.

[23] Igbaria M, Parasuraman S, Baroudi JJ. A Motivational Model of Microcomputer Usage. Journal of Management Information Systems. 1996;13(1):127-43.

[24] Venkatesh V, Davis FD. A Theoretical Extension of the Technology Acceptance Model: Four Longitudinal Field Studies Management Science. 2000;46(2):186-204.

[25] Ajzen I, Fishbein M. Understanding Attitudes and Predicting Social Behaviour. Englewood Cliffs, NJ: Prentice-Hall, Inc; 1980.

[26] Taylor S, Todd PA. Assessing IT Usage: The Role of Prior Experience. MIS Quarterly. 1995;19(2):561-70.

[27] Thompson RL, Higgins CA, Howell JM. Personal Computing: Toward a Conceptual Model of Utilization. MIS Quarterly. 1991;15(1):125-43.

[28] Compeau DR, Higgins CA, Huff S. Social Cognitive Theory and Individual Reactions to Computing Technology: A Longitudinal Study. MIS Quarterly. 1999;23(2):145-58.

[29] Yi MY, Jackson JD, Park JS, Probst JC. Understanding Information Technology Acceptance by Individual Professionals: Toward an Integrative View. Information \& Management. 2006;43(3):350-63.

[30] Waehama W, McGrath M, Korthaus A, Fong M. ICT Adoption and the UTAUT Model International Journal of Information Technology \& Computer Science ( IJITCS ) 2014;17(2):24-30.

[31] Tarhini A, El-Masri M, Ali M, Serrano A. Extending the UTAUT Model to Understand the Customers' Acceptance and Use of Internet Banking in Lebanon: A Structural Equation Modeling Approach. Information Technology \& People. 2016;29(4):830-49.

[32] Alomari M, Sandhu K, Woods P. Measuring Social Factors in E-government Adoption in the Hashemite Kingdom of Jordan. International Journal of Digital Society (IJDS). 2010;1(2):163-72.

[33] Alshehri M, Drew S, AlGhamdi R, editors. Analysis for Citizens' Acceptance for E-government Services: The UTAUT Model. IADIS Inernational Conference: Theory and Practice in Modern Computing and Internet Applications and Research; 2012 17-23 July; Lisbon, Portugal.

[34] Taiwo AA, Downe AG. The Theory of User Acceptance and Use of Technology (UTAUT): A Meta-Analytic Review of Empirical Findings Journal of Theoretical and Applied Information Technology 2013;49(1):48-58.

[35] Khan FA, Ahmad B. Factors Influencing Electronic Government Adoption: Perspectives of Less Frequent Internet Users of Pakistan International Journal of Scientific and Technology Research 2015;4(1):306-15.

[36] Alwahaishi S, Snášel V. Consumers' Acceptance and Use of Information and Communications Technology: A UTAUT and Flow Based Theoretical Model. Journal of Technology Management and Innovation. 2013;8(2):61-73.

[37] Güliz N, Turan AH. E-learning Adoption of Academicians: A Proposal for an Extended Model. Behaviour \& Information Technology 2018;37(4):393-405

[38] Lee D-C, Lin S-H, Ma H-L, Wu D-B. Use of a Modified UTAUT Model to Investigate the Perspectives of Internet Access Device Users.

International Journal of Human-Computer Interaction. 2016;33(7):549-64.

[39] Statistics Mauritius. ICT Statistics Year 2017: Ministry of Finance \& Economic Development; 2018 [Available from: http://statsmauritius.govmu.org/English/Publications/Pages/ICT_Stats_ Yr17.aspx.

[40] International Telecommunication Union. Measuring the Information Society Report 2017 Volume 1. Geneva Switzerland; 2017.

[41] Cheng Y-S, Yu T-F, Huang C-F, Yu C, Yu C-C. The Comparison of Three Major Occupations for User Acceptance of Information Technology: Applying the UTAUT Model. iBusiness. 2011;3(2):147-58.

[42] Schuppan T. E-government in developing countries: experiences from Sub-Saharan Africa. Government Information Quarterly. 2009;26:118-27.

[43] Lai CSK, Pires G. Testing of a Model Evaluating E-government Portal Acceptance and Satisfaction. The Electronic Journal Information Systems Evaluation. 2010;13(1):35-46.

[44] Venkatesh V, Sykes TA, Venkatraman S. Understanding E-government Portal Use in Rural India: Role of Demographic and Personality Characteristicsis. Information Systems Journal. 2014;24:249-69.

[45] Zhou T. The Effect of Flow Experience on User Adoption of Mobile TV. Behaviour \& Information Technology. 2013;32(3):263-72.

[46] Oh J-C, Yoon S-J. Predicting the Use of Online Information Services Based on a Modified UTAUT Model. Behaviour \& Information Technology. 2014;33(7):716-29

[47] El-Masri M, Tarhini A. Factors Affecting the Adoption of E-learning Systems in Qatar and USA: Extending the Unified Theory of Acceptance and Use of Technology 2 (UTAUT2). Educational Technology Research and Development. 2017;65(3):743-63.

[48] Nasser ASA, Sajjab J, Wathiq M. Mobile government (mGovernment) Adoption Factors in the UAE: A Conceptual Framework Based on UTAUT. International Journal of Engineering Technology, Management and Applied Sciences. 2017;5(3):14-9.

[49] Chandra S, C SS, Yin-Leng T. Evaluating the Role of Trust in Consumer Adoption of Mobile Payment Systems: An Empirical Analysis. Communications of the Association for Information Systems. 2010;27(1):561-88.

[50] Lua Y, Yanga S, Chaub PYK, Cao Y. Dynamics Between the Trust Transfer Process and Intention to Use Mobile Payment Services: A Cross-Environment Perspective. Information \& Management. 2011;48(8):393-403.

[51] Belanger F, Hiller JS, Smith, Wanda J. Trustworthiness in Electronic Commerce: The Role of Privacy, Security, and Site Attributes. Journal of Strategic Information Systems. 2002;11:245-70.

[52] Oliveira T, Thomas M, Baptista G, Campos F. Mobile Payment: Understanding the Determinants of Customer Adoption and Intention to Recommend the Technology. Computers in Human Behavior. 2016;61:404-14.

[53] Elsheikh Y, Azzeh M. What Facilitates the Delivery of Citizen-Centric EGovernment Services in Developing Countries: Model Development and Validation Through Structural Equation Modeling. International Journal of Computer Science \& Information Technology (IJCSIT). 2014;6(1):77-98.

[54] Foon YS, Fah BCY. Internet Banking Adoption in Kuala Lumpur: An Application of UTAUT Model. International Journal of Business and Management. 2011;6(4):161-7.

[55] Ponte EB, Carvajal-Trujillo E, Escobar-Rodriguez T. Influence of Trust and Perceived Value on the Intention to Purchase Travel Online: Integrating the Effects of Assurance on Trust Antecedents. Tourism Management. 2015;47:286-302.

[56] Rodrigues G, Sarabdeen J, Balasubramanian S. Factors that Influence Consumer Adoption of E-government Services in the UAE: A UTAUT Model Perspective. Journal of Internet Commerce. 2016;15(1):18-39.

[57] Field A. Discovering Statistics Using SPSS (and Sex and Drugs and Rock 'n' Roll). Third ed. London, California, New Delhi, Singapore: SAGE; 2009

[58] Coe R. It's the Effect Size, Stupid. What effect size is and why it is important. Annual Conference of the British Educational Research Association. University of Exeter, England, 12-14 September 2002: Education-Line; 2002.

[59] Rosenthal R. Meta-analytic procedures for social research. Newbury Park, CA: Sage; 1991.

[60] Cohen J. Statistical Power Analysis for the Behavioral Sciences. Second ed. New York: Lawrence Erlbaum Associates; 1988.

[61] Cohen J. Statistical Power Analysis. Current Directions in Psychological Science. 1992;1(3):98-101.

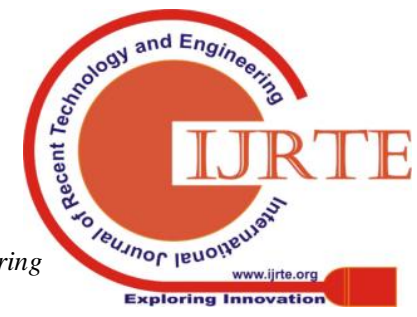


[62] Taipale S. The use of e-government services and the internet: the role of socio-demographic, economic and geographical Predictors. Telecommunications Policy. 2013;37(4/5):413-22.

[63] Dwivedi YK, Lal B. Socio-economic Determinants of Broadband Adoption. Industrial Management \& Data Systems. 2007;107(5):654-71.

[64] Al-Shafi S, Weerakkody V. Understanding Citizens' Behavioural Intention in the Adoption of E-government Services in the State of Qatar. 17th European Conference on Information Systems, ECIS 2009: Information System in a Globalising World: Challenges, Ethics and Practices Verona, Italy 2009.

[65] Sanmukhiya C. E-government Divide in the Republic of Mauritius. International Conference on Social and Management Sciences, Theoretical and Practical Approaches; Singapore: GI Social Sciences Forum; 2017. p. Forthcoming.

[66] CountryMeters. Mauritius Population 2018 [Available from: https://countrymeters.info/en/Mauritius.

67] Taylor S, Todd PA. Understanding information technology usage: a test of competing models. Information Systems Research. 1995;6(2):144-76.

[68] Hwang C-S. A Comparative Study of Tax-Filing Methods: Manual, Internet and Two Dimensional Bar Code. Journal Of Government Information. 2000;27(2):113-27.

[69] Triandis HC. Values, Attitudes, and Interpersonal Behavior. In: Monte PM, Hewe HE, editors. Nebraska Symposium on Motivation 1979 : Beliefs, Attitudes and Values. U.S.: Lincoln, NE, University of Nebraska Press; 1980. p. 195-259.

[70] Alraja MN. The Effect of Social Influence and Facilitating Conditions on E-government Acceptance from the Individual Employee's Perspective. Polish Journal of Management Studies. 2016;14(2):18-26.

[71] Duane A, O'Reilly P, Andreev P. Realising M-Payments: Modelling Consumers' Willingness to M-Pay Using Smart Phones. Bahaviour and Information Technology. 2014;33(4):318-34.

[72] van Dijk, Jan A. G. M, Peters O, Ebbers W. Explaining the Acceptance and Use of Government Internet Services: A Multivariate Analysis of 2006 Survey Data in the Netherlands. Government Information Quarterly. 2008;25(3):379-99.

[73] Islam AM, Yusuf HM, Bhuiyan AB. Taxpayers' Satisfaction in Using E-filling System in Malaysia: Demographic Perspective. The Social Sciences. 2015;10(2):160-5.

[74] Dwivedi YK, Rana NP, Jeyaraj A, Clement M, Williams MD. Re-examining the Unified Theory of Acceptance and Use of Technology (UTAUT): Towards a Revised Theoretical Model. Information Systems Frontiers. 2019;21(3):719-34.

[75] Pina V, Torres L, Royo S. Is E-Government Promoting Convergence Towards More Accountable Local Governments? . International Public Management Journal. 2010;13(4):350-80.

[76] Alshawi S, Alalwany H. E-Government Evaluation: Citizen's Perspective in Developing Countries. Information Technology for Development. 2009;15(3):193-208

[77] Slade EL, Dwivedi YK, Piercy NC, Williams MD. Modeling Consumers' Adoption Intentions of Remote Mobile Payments in the United Kingdom: Extending UTAUT with Innovativeness, Risk, and Trust. Psychology and Marketing. 2015;32(8):860-73.

[78] Wirtz BW, Mory L, Piehler R, Daiser P. E-government: A Citizen Relationship Marketing Analysis International Review on Public and Nonprofit Marketing. 2017;14(2):149-78.

\section{AUTHOR PROFILE}

I am Chintamanee Sanmukhiya My affiliation is Greenwich university department of economics and finance. My area of expertise is qualitative analysis, research methodology. 